\section{Call for more data forms basis of Bush climate strategy}

Tony Reichhardt, Washington

Improved computer models, accelerated studies of the global carbon cycle, and standardization of climate data are among the priorities listed in the Bush administration's draft strategy for climatechange research, released on 11 November.

The plan sets an overall direction for the Climate Change Science Program, which was created last year to address near-term uncertainties in climate science. The new programme merged the \$1.7-billion, multi-agency US Global Change Research Program (USGCRP) with the narrower \$40-million Climate Change Research Initiative.

The new strategy acknowledges that global warming is under way, but reflects the Bush administration's wariness on the subject by emphasizing gaps in knowledge that need to be filled before policy-makers can make confident decisions.

As well as listing high-priority research needs, such as characterizing atmospheric aerosols, the plan calls for investment in observational networks, including an Integrated Ocean Observing System.

The strategy will now undergo extensive review, starting with a workshop in Washington next month for scientists and policy-makers. It also will be vetted by a fast-track National Academy of Sciences panel chaired by Thomas Graedel, director of Yale University's Center for Industrial Ecology. A final version of the plan is expected to be released next April.

The plan's authors say that they relied heavily on previous academy reports that outlined priorities for climate-change research. But conspicuously absent from the document is any mention of the controversial 'National Assessment' published by the USGCRP in 2000, which described possible regional affects of climate change in the United States. The new strategy states flatly that modelled projections "are often contradictory and are not sufficiently reliable tools for planning".

The National Assessment infuriated global-warming sceptics, who sued to prevent its release, charging that it was politically motivated. The anger has not subsided. Last month Christopher Horner, a senior fellow at the Competitive Enterprise Institute (CEI), a public-policy organization based in Washington, called for members of the team that produced the National Assessment to be barred from next month's workshop.

www.climatescience.gov

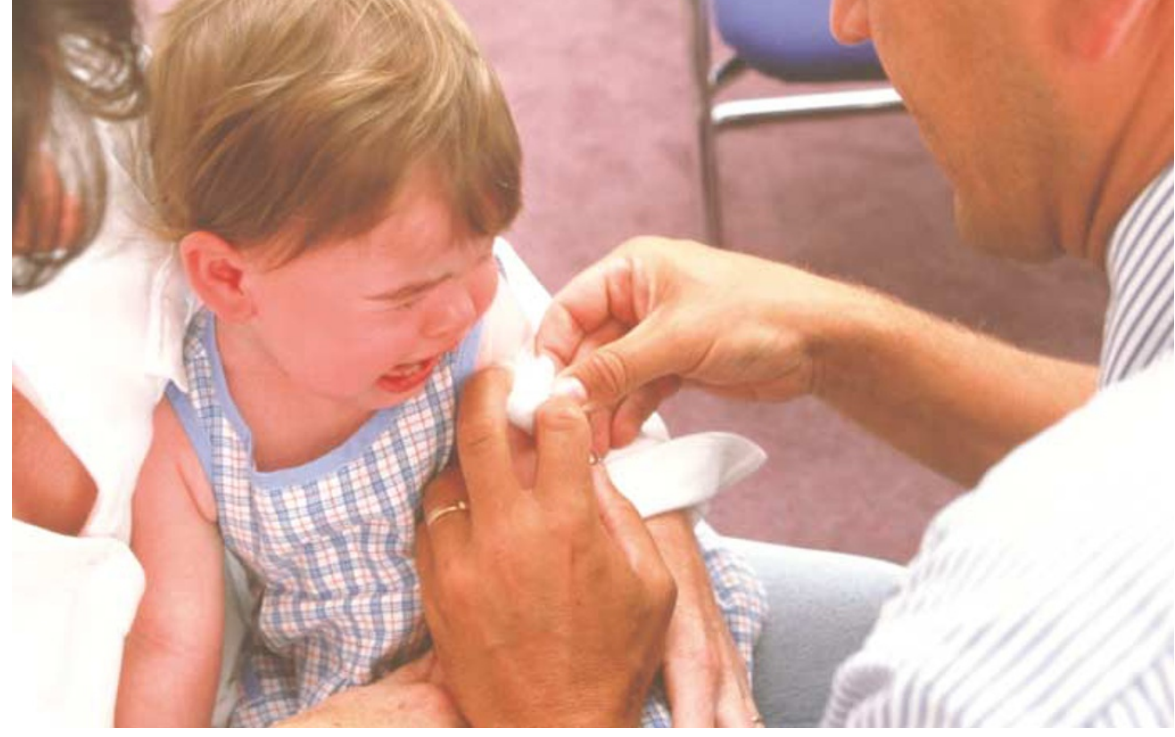

Many critics argue that using small children in a trial for a smallpox vaccine poses too greater a risk.

\title{
Outcry greets US plan to test smallpox vaccine on children
}

Erika Check, Washington

Plans to test a smallpox vaccine on small children in the United States have been slammed by critics who claim that the trial is unnecessary and potentially harmful.

The government wants to give 40 children, aged 2-5, doses of the Dryvax smallpox vaccine. Half would get a diluted form of the vaccine, and the rest would receive the fullstrength version. The study, which would be funded by the National Institute of Allergy and Infectious Diseases in Bethesda, Maryland, would aim to assess the safety and efficacy of the diluted vaccine stockpile.

But the planned trial was greeted with a flood of criticism when details were posted on the website of the Food and Drug Administration (FDA) on 31 October as part of the public-review process.

The Department of Health and Human Services (DHHS) convened a panel of 10 experts - clinicians, lawyers and pharmacists - to examine the ethical questions raised by the proposed study. In their comments, which are also posted on the FDA's website, most of them agreed that there is a case for going ahead with the trials.

The study raises important questions, says Mary Faith Marshall of the University of Kansas Medical Center, who is former chair of the now-disbanded National Human Research Protections Advisory Committee and a member of the expert panel. For instance, she says, the risk of a smallpox attack is low, and an attack would probably affect just a few geographical regions. So most of the children who participate in the study will probably never be involved in an attack — and so would be unlikely to benefit from the study. On the other hand, between two and ten children out of every million could develop life-threatening side-effects from the vaccination.
Marshall points out, however, that the panel of experts recognized that the risk of an attack is not zero. And a smallpox attack would be deadly, killing about $30 \%$ of infected individuals. "That argues more strongly than if the mortality was not as high," says Marshall.

But others disagree with the panel members' general approval of the proposal. They point out that despite the Bush administration's assertions that Iraq has stockpiles of smallpox virus, there is still no proof that it or other nations are planning to attack the United States with germs. And, they say, scientists are already developing a safer version of the vaccine, which will probably need to be tested in children anyway.

"The risks of the Dryvax vaccine are clear - and the fact is that death can occur even in normal, healthy children," says Paul Offit, chief of infectious diseases at the Children's Hospital of Philadelphia in Pennsylvania and a member of the Advisory Committee on Immunization Practices, which advises the DHHS on vaccine policy. "There could be children who suffer from the vaccine who never had any chance of suffering the disease."

And $\mathrm{Al}$ Sommer, dean of the Johns Hopkins Bloomberg School of Public Health in Baltimore, Maryland, points out that young children are not at high risk of contracting smallpox in the event of a bioterrorist attack. Also, he notes, earlier experience with the vaccine indicates that young children are unlikely to respond to the vaccine differently from adults. "None of this makes any sense from a public-health perspective," Sommer says.

The FDA is accepting public comments on the smallpox trials until 2 December. The federal health secretary and the head of the FDA will then issue a final decision on the trials. 